UDC: 158.923

DOI: https://doi.org/10.24195/2414-4665-2017-3-10

\author{
Natalia Volodarska, \\ PhD (Candidate of Psychological Sciences), leading researcher of \\ Kostyuk Institute of Psychology, \\ National Academy of Educational Sciences of Ukraine, \\ 52-A Sichovykh Striltsiv Str., Kyiv, Ukraine, \\ Oksana Chornopyska, \\ PhD (Candidate of Psychological Sciences), associate professor, \\ Psychiatry, Narcology and Medical Psychology Department, \\ Ivano-Frankivsk National Medical University, \\ 2, Halytska Str., Ivano-Frankivsk, Ukraine
}

\title{
CHANGING LIFE PERSPECTIVES AND STRATEGIES OF ATO PARTICIPANTS' FAMILIES IN CRISIS SITUATIONS
}

The fighting in Eastern Ukraine (the armed conflict in the Donbass Region of Ukraine (2014 - present)), that is a real war today, has provoked a great number of problems in psychosocial adaptation of soldiers and today the issue of the military men's psychological rehabilitation is considered to be one of the most urgent and relevant problems. The paper aims to determine particularities of changing life prospects and strategies of ATO participants' families in crisis situations after the implementation of the designed trainings. The survey involved the carrying out of psychological support for couples (38 persons) who were receiving treatment in the rehabilitation center "Khyriv-Rent-Invest" Khyriv city. The empirical survey included projective techniques: drawings "Island of my dream" and "Our House". Psychological support involved individual counseling, group sessions with discussing life situations of both - men and their wives - and the art therapy. The carried out analysis has shown the peculiarities of life perspectives of ATO participants' families. Thus, in crisis situations the way of solving everyday problems by men and women changes. These alterations concern building life perspectives, goals and means of their achieving. The psychological support of a couple in crisis situation involves family therapy, counseling, individual and group sessions. In this way life perspectives (recovery of time-spatial representations of the past, present and future) of men and women can be corrected. Psychological personality support of ATO participants' families in crisis situations is aimed at harmonization of their life perspectives and activation of self-identity process.

Keywords: life strategies, ATO participants, psychological rehabilitation, crisis situations, changes of men and women life perspectives.

\section{Introduction}

Today one of the most significant issues in Ukrainian psychology is psychological rehabilitation of AntiTerrorist Operation (ATO) Zone participants.

Naturally soldiers, mainly men, are the direct victims of military operations. They have been exposed to traumatic events, such as bombings, shootings and injuries. Militaries in Eastern Ukraine everyday see the death of their friends; young men often come back home disabled. The fighting in Eastern Ukraine (the armed conflict in the Donbass Region of Ukraine (2014 - present)), that is a real war today, has provoked a great number of problems in psychosocial adaptation of soldiers. The question is how the society will live after a new war. The implicit effects of the armed conflict are as obvious and important as the explicit ones. The participation of soldiers in the conflict has serious implications for their physical and emotional well-being. The psychological emotional consequences of the heavy fighting are worsening. It leads to changes of soldiers' life prospects that become more unpredicted and diverse.

The psychological state of a soldier who has returned to peaceful life is very important. The main reason is traumatic stress which often occurs during the war and becomes one of the major internal barriers to peaceful life adaptation. Post-traumatic stress disorders lead to the formation of specific family relations, special life scenarios and can affect the rest of their life. Most of the soldiers who have come back from the ATO Zone often dwell on their life paths: they are looking for new perspectives and values. The family members face a lot of difficulties in perception of men who have returned completely different from the war as well. As a result, the necessity for changes of life strategies of ATO participants and their families is quite obvious.

There are some studies which point to a causal link of military conflicts. In the paper "Civil wars kill and maim people - long after the shooting stops" Ghobarah, Huth \& Russett claim that wars have long-term consequences on civilian suffering (Ghobarah, Huth, \& Russett, 2003). In spite of the size of the health effects, an armed conflict has not received so much attention of public health research as many other reasons of diseases and death (Murray, King, Lopez, Tomijima, \& Krug, 2002).

The local scientists Leontyev and Titarenko studied theoretical basis of individual life strategies (Leontyev, 
2002; Titarenko, 2003); the investigations of traumatic effects on human social adaptation were conducted by Volodarska (Volodarska, 2004; Volodarska, 2014; Volodarska, 2016); Kennedy and Garret revealed features of the inner world of personality with disabilities (Kennedy, 2007; Garrett, 2003); Zelenova researched the phenomenon of posttraumatic stress disorder (PTSD) among military men (Zelenova, 2005). Recent studies intended to determine the conditions of recovery personal resources and overcoming the effects of trauma (Carlson, \& Ruzek; Kisarchuk, Omelchenko, Lazos \& others, 2015; Lawrence, Smith, \& Sega, 2016; Williams, \& Poijula, 2013). According to modern views on the psychology of personality, changes in creating life prospects, goals and strategies of their achievement have gender differences (Kalynauskas, 2011). Until recently, no particular attention was paid to the gender-specific aspects of the negative impacts of military conflicts. The indirect consequences of wars also affect women - arguably even more than men. Thomas \& Neumayer analyzed the impact of armed conflicts on female life expectancy relative to male (Thomas, \& Neumayer, 2006). Therefore, the issue of determination and correction of life prospects, goals and strategies of soldiers who have been in the area of armed conflict and their families is considered to be relevant. It is the key to their successful adaptation to civilian life.

The paper aims to determine particularities of changing life prospects and strategies of ATO participants' families in crisis situations after the implementation of the designed trainings.

\section{Discussion}

Life strategy is a way of human life organization, the ability to adjust one's living conditions in line with one's values and individuality (Abulkhanova-Slavska, 1991). Life strategy of an individual is a quite stable formation, which is based on his/her value orientations and life senses.

Values may be described as some ideal goals that set the benchmark in evaluating certain events; most stable motivational formations which define life in general. They have a high degree of stability. Values are criteria for selection according to which a person builds his/her attitude to the surrounding world.

As a complicated formation, the coordinated life perspective means established ideas about the future, demonstrates the ability of an individual to the effective self-fulfillment, his/her willingness to make decisions and act independently under new unusual conditions. Such stability provides relative independence from the influences of the environment. Thus, based on values, life strategies are stable and resistant. They organize integrity of life and determine human existence. Life strategy is one of the regulators of social behavior.

In Leontyev's concept, the life senses are considered in three opposite perspectives: "sense - value"; "sense emotion"; "sense - absurdity" (nonsense) (Leontyev, 2002).
In the first case "sense" is derived from the fundamental opposition of knowledge and relations as a unit of objective knowledge of reality. Thus, sense is a unit of objective attitude towards reality. This first meaning of sense abstracts from specific form of its existence in consciousness.

The second one is the opposition of "sense and emotion", where emotion is a direct expression of person's attitude to certain events and situations, and sense is mediated by values and general cognition of oneself and one's own life. The sense is an emotion with value, emotion, enlightened by opinion.

The third opposition "awareness - absurdity" has quite different origin. Its source is the "forming meaning motive" concept. Only when an individual's activity and the general course of events are aimed at realization of sense-forming motives, the situation is considered to have a certain sense. Otherwise, it becomes absurd.

It is known that a person may not always perceive a crisis situation with some sense (this is the situation of returning a soldier from ATO Zone). Characteristically, the values of an individual in crisis situation change. Instead of being transformed into their own hierarchy of values, they become diffuse. The rejection of values dissimilated into the inner world causes conflict of the aims. For instance - the desire to "live well" and "do nothing", "get money for nothing", etc. In this case there is a gap in human interaction with reality, with others, the society, and, as a consequence, with self. Thus, a person starts experiencing conflicting emotions with other people and himself/herself, which creates cognitive dissonance.

The state of uncertainty is accompanied by various negative experiences: the emergence of frustration, feeling non-confident, confusion, oppression. A personality tries to adapt to the life with such defense mechanisms as sublimation, regression, isolation, denial, introjection, projection, rejection. Caring, politeness might be "reactive formations" through which a personality is trying to be protected against his/her aggressive instincts. Thus, the "cost" of errors in goal-setting, means of achieving goals, obtained results and missed opportunities of an individual increases.

Changes of the immediate circle affect the system of life perspectives and strategies of an individual. Especially it happens in crisis situations. An important stage in the process of life perspectives changing of ATO participants and their families is harmonization of their inner world, awareness of their value. In this context, the question of rethinking of life strategies of an individual in the new environment arises. It is important to take into account the psychological support technologies as well, which cannot be transformed according to person's needs in a crisis situation because of low flexibility and imperfection.

\section{Methods}

The survey involved the carrying out of psychological support for couples (38 persons) who were receiving treatment in the rehabilitation center "Khyriv-RentInvest" Khyriv city (Sambir district, Lviv region, 
Ukraine), where special services are provided for psychological rehabilitation of injured ATO participants.

The empirical survey included projective techniques: drawings "Island of my dream" and "Our House".

Psychological support involved individual counseling (twice a week for one hour), group sessions (once a week for three hours) with discussing life situations of both - men and their wives - and the art therapy (family sculptures). These meetings were conducted throughout the rehabilitation period (30 days). The complexities of the participants' problems, their needs and necessities were discussed. Changes in pictures were analyzed from the very beginning to the end of the rehabilitation period (the color, amount of new figures in the drawings, interpretations represented by a wife and a husband).

\section{Results and discussion}

In general, life strategies of men and women have clearly defined gender-role differences. Female consciousness is fundamentally different from that of men. Family values, housekeeping skills remain unchanged for women. Women interaction with social environment is characterized by providing space for dialogue, its filling and exploration. Professional activity, social activity, office success are desirable life values for men (Lindsay, 2010). Successful self-fulfillment of a man is associated with his career, status, and financial resources. Controlling interaction, establishing, maintaining or suspending relations are typical interaction stereotypes of men. Kalynauskas indicates the main criterion of success in a man's world: "All advantages in this world, competitive world, the world of achievement, the world of organization, are issued from these rules - to participate and win" (Kalynauskas, 2011).

A comparative analysis of the couples' life prospects in crisis situations was conducted based on Kalynauskas' highlighted patterns of specific male and female stereo- types of interaction with the social environment and people. For this purpose, the respondents were asked a number of questions about changes in the life plans and prospects. The comments of the couples were analyzed. While the interviewees were drawing the dream island (the technique "Drawing "Island of my dream") they were asked: "Who would you like to settle on the island? Describe your life on the island. What would you like to change?" Answering these questions, the young couples showed anger, wished to stay alone on the island, to see nobody. The pictures were drawn with little details in dark colors (black, brown, a bit green). They looked more like a topographical map.

Analysis of the men's drawings has showed their increased anxiety and self-doubt (76\%). This was evidenced by thin lines or very strong pressure of a pencil. All women $(100 \%)$ tried to control the process of drawing the house, not just decorating it, but making its detailed sketch. Then they criticized, ridiculed or devaluated their inceptions. Thus in men's life strategies the interest from control and organization of actions has shifted to submission and criticism. Women changed their strategies as well - from strategy of filling the space to management and organization actions. As a rule, such changes occur mainly in crisis situations (loss of health, of material wealth, apartment for living, work, opportunities of free life choice).

The analysis of the respondents' answers to questions concerning the most important topics of men and women (Changing of residence, Changing living conditions, Changing work, Changing relations in couple, Continuation of studying, Childbirth, Reviewing family budget, Benefits) has made it possible to single out certain patterns in manifestations of their life perspectives (results are shown in Figure 1).

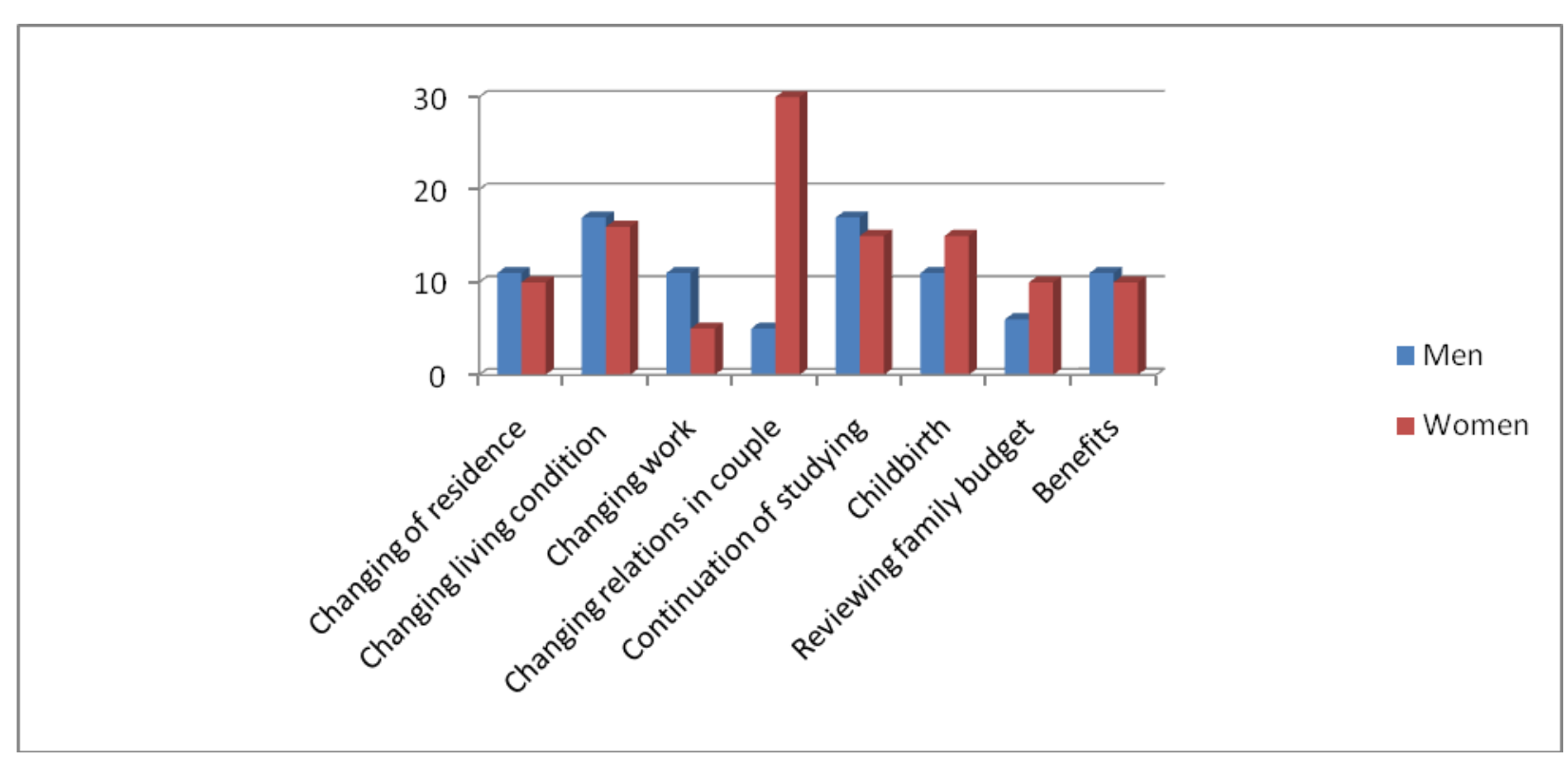

Pic. 1. Differences of "life perspectives themes" of men and women 
Analyzing the discussions of life prospects themes, the most relevant topics for women are "changing relations in couple" (30\%), "changing living conditions" (15\%) and "having a baby" (15\%). For men these topics are "continuation of studying" $(27 \%)$, "changing living conditions" (17\%), "changing of residence" $(11 \%)$, "benefits" (11\%), "changing of job" (11\%) and "childbirth" $(11 \%)$.

If a couple has hard times (living with parents, the lack of money to rent a new place of living, the need for treatment elsewhere, changing school and children kindergarten), the main cause of controversy is discussing and planning moving to another place.

Crisis situations have affected the changes in the activity of choosing alternative means to achieve goals. For instance, $71 \%$ of men began to manifest more passivity in solving household problems. In making decisions about relocation and finding another job the opinions of women had a priority. The same situation concerned the issues of the first or second childbirth.

The qualitative analysis of answers has led to the conclusion that senses and values of men are changing daily in crisis situations. Mixed type of stereotypes appears. Since stress causes regression in manifestations of psychological defense, the state of frustration, unwillingness to interfere in the solving problem arises frequently. The men have no significant values and senses, therefore, their lives are devaluated.

Specific goals and plans are the key point in researching human life perspectives. According to them a person intends to realize his/her values. It should be remembered that the development of individual life strategies is based on the adequacy of time representations of life prospects, meaningfulness of life path, future perspectives, past achievements and confidence in one's own capabilities.

For the men who were in the ATO Zone the past events were more important and predominant. In the discussions of significant life events they reminded parties with their friends, peers in the past. They tried to avoid talking about their traumatic participation in ATO, insults that have emerged during these events. Only sometimes they mentioned memories of what had happened. Remembering the traumatic situations men have noted unfairness concerning the pension, treatment, benefits and social insecurity (11\%). Emotional excitement, shouting, anger, aggressive behavior could be observed in these moments.

Men could not focus on planning their family future. Although they have noted the necessity to obtain new occupation, education (entering university, taking training courses) $(27 \%)$, to change job (getting visa to go abroad for job hunting) (11\%); often their plans did not have a real background. Some of them attempted to change the profession radically in order to get larger disposable income. Temporary job with higher salary had priority for them. Men considered that they should live for the day, enjoy life, spend money earned earlier, not always ration- ally - to drink with friends, to have fun and relax. Apparently the militaries who saw death sought to live for the day without any ambitious plans for the future.

So, getting the question: "What changes do you plan in your family, work, rest?" - $65 \%$ men were pondering and pausing, started to look at their wives, trying to shift the responsibility for planning the future to them. Features of men's life perspectives changes in crisis situations have emerged in such psychological defenses as rejection, avoiding and non-recognition of the problems.

If men cannot make a decision, women become active, try to take responsibility for themselves. Kalynauskas indicates "If there is no one to rescue and protect, the woman herself is going to do it. She has an instinct like wolf, which is protecting the progeny, without hesitation comes into the fight with the wolf and man ... This conflict is akin to a civil war - it is impossible to win" (Kalynauskas, 2011).

For one third of women $(30 \%)$ the relationship with their husbands were significant. So they were actively planning such changes in the family as a choice of other rehabilitation center for their men, hospital for further treatment, new places for recreation with the husbands, moving to another city, changing job for both of them or only husbands, having babies, the selection of school for their children, continuation of their husbands' education or changing the university.

Obviously, the role of women in finding sense of purpose by their husbands is extremely important. Further rehabilitation and welfare of the family depends on women. If a woman does not encourage the initiatives of her husband in changing life perspectives by his own (returning to his usual rhythm of professional activity, insisting on changing work habits, friends, etc.), then the passivity of her husband arises in organization changes, establishing dialogue with her and others. Such changes in his behavior lead to increasing negative effects in communication, rehabilitation as a whole. Moreover, during consultations women were insulted by the passivity of men in life plans changing, searching for the alternatives for future work, possibilities of solving life's problems, domestic problems.

One of the reasons of women's limitations in the life choices is their husbands' injuries, instability in material welfare, work. Confusion of women in a crisis situation may change their life strategies stereotypes in behavior, their emotional spheres, which makes it impossible to change the life perspectives. Changing typical female stereotypes of interaction towards greater activity of women in solving life's problems causes feeling of loneliness. In contrast, if a woman shifts responsibility towards a husband in building life perspective changes, she feels protected and confident, feminine identity is acquired. In this interaction there is no struggle for power, no boss and subordinate as well, there is harmony in the relationships. Awareness of woman's identity makes her follow the life path chosen by her man. Consequently, the main woman's task is to fill this space, to take the next 
step in the cycle of interaction with a man, to overcome a pause between the end of one phase of interaction and the beginning of a new one.

The next step after having determined the problem areas in the relationship of the couples was to activate searching for the personal resources of the surveyed by applying art therapy techniques. The exercises were focused on the needs of the couple.

The drawings "Our House" that were performed during the second half of staying at the center have shown positive dynamics. $89.4 \%$ of pictures of men and women were more detailed and had vibrant colors. Men have become more active in the interpretation of images. The paintings included figures of neighbors, animals, planned changes in the place of residence, terms of house construction. More and more men actively took part in discussions about changing the profession (differences in desires to move to another country for work, the choice of new places for work, education and recreation), place of residence $(88.2 \%)$. Strategies of therapeutic interventions were aimed at expansion of life perspectives changes of soldiers, finding their personal resources to support the implementation of these plans. In case of disability of military men, the possibility of changing profession was considered (variants of forms of education were discussed).

Therefore, discussion of new plans during individual and group sessions had a positive impact on solving internal family conflicts. Expansion of worldview orientations helped family couples with different religious believes (Catholic and Orthodox, Muslim and Orthodox and others) to resolve conflicts. The acceptance of personal identity (on the grounds of faith, gender and nation) helped to accept the dissimilarities in partner and to be tolerant in relationship.

Analyzing paintings of the couples, as well as comments of husbands and wives at the end of 30-day rehabilitation, a positive trend is noted. Answering the question "What can you change in your nearest future?" $95 \%$ of respondents mentioned opportunities of changes - enter the university, move to another place of residence, find possibilities to help their parents, to come back to the ATO zone after treatment in hospital and undergo rehabilitation. Future plans of couples have become more adequate to their material-based possibilities and estimation of physical resources as well. There were changes in the husbands' attitudes to psychotherapy opportunities (especially individual). $67 \%$ of soldiers started actively showing interest in the psychological rehabilitation. If initially they were led by their wives, later they agreed to undergo treatment, accepted recommendations of doctors and psychologists.

During the group sessions the internal attitudes of couples have changed into positive ones. $89 \%$ both men and women have become more competent in the commu- nication area, learned to detect their emotions and feelings, realized and tried to change their attitude to crisis events; the priority value orientations and life senses have been defined. This was confirmed by the changes in the group drawings and individual sessions in couples (at the end of rehabilitation). The couples began to show interest in each other, there were fewer expressions of anger, aggression in the statements, more creativity, positive views on the ways out of crisis situations, humor in assessing their own capabilities. Both spouses ceased to devalue their life path, exaggerate difficulties in overcoming the crisis (in the professional achievements, the difficulties of present and future plans). Thus, the person returns to reality, all memories become positive; an interest in new areas appears.

Consequently, during consultations a psychologist takes into account the particularities of individual life perspectives based on the development of individual life strategies.

\section{Conclusions}

The carried out analysis has shown the peculiarities of life perspectives of ATO participants' families. Thus, in crisis situations (loss of health, material wealth, apartment for living, work and opportunities of free life choice etc.) the way of solving everyday problems by men and women changes. These alterations concern building life perspectives, goals and means of their achieving.

The mixed type of life stereotypes is peculiar for men: unwillingness to interfere in solving problems and shifting the responsibility to women. The state of frustration, manifestations of devaluating their life, absence of significant values and senses occur frequently. Features of men's life perspectives changes in crisis situations have emerged in such psychological defenses as rejection, avoiding and non-recognition of the problems.

In crisis situations women change life strategies stereotypes in behavior, which are peculiar to their female nature and emotional sphere as well. Instead of filling and mastering space strategy women choose the strategy of management and organization actions. Women become more active in resolving their family life's problems.

The psychological support of a couple in crisis situation involves family therapy, counseling, individual and group sessions. In this way life perspectives (recovery of time-spatial representations of the past, present and future) of men and women can be corrected.

Psychological personality support of ATO participants' families in crisis situations is aimed at harmonization of their life perspectives and activation of selfidentity process.

\section{REFERENCES}

1. Abulkhanova-Slavska, K. A. (1991). Strategiya zhizni [Strategy of life]. Moscow: Mysl [in Russian].

2. Carlson, E. B., \& Ruzek, J. Effects of Traumatic Experiences. Retrieved from:

http://web.stanford.edu/group/usvh/stanford/misc/PTSD\% 20-\%20Effects\%20of\%20Traumatic\%20Experiences.pdf.

3. Garrett, J. F. (2003). Psychological Aspects of Physical Disability 
4. Ghobarah, H. A., Huth, P., \& Russett, B. (2003). Civil Wars Kill and Maim People - Long After the Shooting Stops. American Political Science Review, 2, 189-202 (Vol. 97).

5. Kalynauskas, I. (2011). Zhenskaya mudrost $i$ muzhskaya logika. Voina polov ili printsyp dopolnitelnosti [Women's wisdom and men's logic. War of the sexes or principle of complementation]. Saint Petersburg [in Russian].

6. Kennedy, P. (2007). Psychological Management of Physical Disabilities: a practitioner's guide. $1^{\text {st }}$ ed. Routledge.

7. Kisarchuk, Omelchenko, Lazos \& others. (2015). Psykholohichna dopomoha postrazhdalym vnaslidok kryzovykh travmatychnykh podii: Navchalno-metodychnyi posibnyk [Psychological help to victims injured in crisis traumatic events. Textbook]. Kyiv [in Ukrainian].

8. Lawrence, R., Smith, M., \& Sega, J. (2016). Emotional and Psychological Trauma. Retrieved from: http://www.helpguide.org/articles/ptsd-trauma/emotionaland-psychological-trauma.htm.

9.Leontyev, D. (2002). Lichnostnoe v lichnosti: lichnostnyy potentsial kak osnova samodeterminatsii [The personal of the person: personal potential as the basis of self-determination]. Uchenye zapiski kafedry obshhey psikhologii MGU ym. M. V. Lomonosova - Scientific notes of the department of general psychology, 1 . Moscow [in Russian].

10. Lindsay, L. L. (2010). Gender roles. A sociological perspective. Fifth edition. London: Pearson.

11. Murray, C. J. L., King, G., Lopez, A. D, Tomijima, N., \& Krug, E. G. (2002). Armed conflict as a public health problem. BMJ. (Vol. 324). 9 February. (p. 346349). Retrieved from: http://gking.harvard.edu/files/armedph.pdf.

12. Titarenko, T. M. (2003). Zhyttievyi svit osobystosti: $u$ mezhakh i za mezhamy budennosti [The life world of the individual, within and beyond routine]. Kyiv [in Ukrainian].

\section{ЛІТЕРАТУРА}

1. Абульханова-Славская К. А. Стратегия жизни / К. А. Абульханова-Славская. - М.: Мысль.

2. Carlson Eve B., Ruzek Josef. Effects of Traumatic Experiences [Електронний pecypc] / B. Carlson Eve, Josef Ruzek. - Режим доступу: http://web.stanford.edu/group/usvh/stanford/misc/PTSD\% 20-\%20Effects\%20of\%20Traumatic\%20Experiences.pdf

3. Garrett J. F. Psychological Aspects of Physical Disability / J. F. Garrett. -2003. - 208 p.

4. Ghobarah H. A. Civil Wars Kill and Maim People - Long After the Shooting Stops / H. A. Ghobarah, P. Huth \& B. Russett // American Political Science Review. - Volume 97. - Issue 2. - May 2003. P. 189-202.

5. Калинаускас И. Женская мудрость и мужская логика. Война полов или принцип дополнительности / И. Калинаускас. - СПб.: Изд-во “Афина”, 2011. - 224 c.
13. Thomas, P., \& Neumayer, E. (2006). The Unequal Burden of War: The Effect of Armed Conflict on the Gender Gap in Life Expectancy. Intemational Organization. Vol. 60, No. 3 (Summer). Cambridge University Press. p. 723-754.

14. Zelenova, M. E. (2005). Issledovaniya smyslozhiznennykh oryentatsyy u veteranov boevykh deistviy $\mathrm{v}$ Afganistane [Investigations of life orientations of veterans fighting in Afghanistan]. Boevoy stress: Mekhanizmy stressa $v$ ekstremalnykh usloviyakh - Combat stress: Mechanisms of stress in extreme conditions. Moscow [in Russian].

15. Volodarska, N. D. (2004). Sotsialno-psykholohichni chynnyky sotsialnoyi intehratsii molodi z somatychnymy vadamy zdorovya: Naukovo-metodychnyi posibnyk [Sociopsychological factors of social integration of young people with somatic disabilities. Scientific methodical manual]. Kyiv [in Ukrainian].

16. Volodarska, N. D. (2014). Aktyvizatsiia protsesu samotvorennia metodamy grupovoi terapiyi [Activation of self-creation process by group therapy methods]. Problemy humanitarnykh nauk: zb. nauk. prats Drogobytskoho derzhavnoho pedahohichnoho universytetu imeni Ivana Franka Humanities: collection of scientific works of Drogobych state pedagogical university named after Ivan Franko, 33, 17-28. Drohobych [in Ukrainian].

17. Volodarska, N. D. (2016). Perspektyvy zastosuvannia metodiv dialohovoi psykhoterapii v umovakh suspilnykh transformatsii [Perspectives of application interactive psychotherapy methods in social transformations conditions]. Naukovyi visnyk Khersonskoho derzhavnoho universytetu. Seriya "Psykholohichni nauky" - Bulletin of Kherson state university. psychology, 2, 24-30 (Vol. 1). Kherson [in Ukrainian].

18. Williams, M. B., \& Poijula, S. (2013). The PTSD Workbook: Simple, Effective Techniques for Overcoming Traumatic Stress Symptoms. Paperback.

6. Kennedy P. Psychological Management of Physical Disabilities. A practitioner's guide / P. Kennedy. Routledge. - 2007. - 296 p.

7. Кісарчук 3. Г. / Психологічна допомога постраждалим внаслідок кризових травматичних подій навчально-методичний посібник / 3. Г. Кісарчук, Я. М. Омельченко, Г. П. Лазос, Л. І. Литвиненко, Царенко Л. Г.; за ред. З.Г. Кісарчук. - К.: ТОВ “Видавництво "Логос", 2015. - 207 с.

8. Lawrence R. Emotional and Psychological Trauma [Електронний ресурс] / R. Lawrence, M. Smith, J. Sega. Режим доступу: http://www.helpguide.org/articles/ptsd-trauma/emotionaland-psychological-trauma.htm

9.Леонтьев Д. Личностное в личности: личностный потенциал как основа самодетерминации / Д. Леонтьев // Ученые записки кафедры общей пси- 
хологии МГУ им. М. В. Ломоносова. - Вып. 1. - М.: Смысл, 2002. - С. 56-65.

10. Lindsay L. Linda. Gender roles. A sociological perspective / Linda L. Lindsay. - Fifth edition. - London: Pearson, 2010. -528 p.

11. Murray C. J. L. Armed conflict as a public health problem [Електронний ресурс] / C. J. L. Murray, G. King, A. D. Lopez, N. Tomijima, E. G. Krug // BMJ. Vol. 324. - 2002. - Р. 346-349. - Режим доступу: http://gking.harvard.edu/files/armedph.pdf

12. Титаренко Т. М. Життєвий світ особистості: у межах і за межами буденності / Т. М. Титаренко. - К.: Либідь, 2003. - 376 с.

13. Thomas P. The Unequal Burden of War: The Effect of Armed Conflict on the Gender Gap in Life Expectancy / P. Thomas, E. Neumayer // International Organization. - Vol. 60. - No 3 (Summer) 2006. - pp. 723-754.

14. Зеленова М. Е. Исследования смысложизненных ориентаций у ветеранов боевых действий в Афганистане / М. Е. Зеленова // Боевой стресс: Механизмы стресса в экстремальных условиях / Марина Евгеньевна Зеленова - М.: Истоки, 2005. - С. 91.
15. Володарська Н. Д. Соціально-психологічні чинники соціальної інтеграції молоді з соматичними вадами здоров'я: науково-методичний посібник (за заг. ред. Володарської Н.Д.) / Н. Д. Володарська. - К.: Міленіум, 2004. - 186 с.

16. Володарська Н. Д. Активізація процесу самотворення методами групової терапії / Н. Д. Володарська // Проблеми гуманітарних наук: зб. наук. праць Дрогобицького державного педагогічного університету імені Івана Франка) / ред. кол. Н. Скотна (гол. ред.), І. Галян та інш. Дрогобич: Редакційно-видавничий відділ ДДПУ імені Івана Франка. - 2014. - Вип. 33. Психологія. - С. 17-28.

17. Володарська Н. Д. Перспективи застосування методів діалогової психотерапії в умовах суспільних трансформацій / Н. Д. Володарська // Науковий вісник Херсонського державного університету. Серія "Психологічні науки". - Випуск 2. - Том 1. - Херсон, 2016. - C. 24-30.

18. Williams M. B., Poijula S. The PTSD Workbook: Simple, Effective Techniques for Overcoming Traumatic Stress Symptoms / M. B. Williams, S. Poijula. $-2013 .-353 \mathrm{p}$.

\section{Наталія Дмитрівна Володарська, кандидат психологічних наук, старший науковий співробітник, провідний науковий співробітник Інституту психології імені Г. С. Костюка, Національна академія педагогічних наук України, вул. Січових Стрільиів, 52-А, м. Київ, Україна, \\ Оксана Петрівна Чорнописка, кандидат психологічних наук, доиент кафедри психіатрії, наркологї та медичної психологї, Івано-Франківський національний медичний університет, вул. Галицька, 2, м. Івано-Франківськ, Украӥна}

\section{ЗМІНИ ЖИТТЕВИХ ПЕРСПЕКТИВ ТА СТРАТЕГІЙ СІМЕЙ УЧАСНИКІВ АТО В КРИЗОВИХ СИТУАЦІЯХ}

У статті проаналізовано проблеми психологічної реабілітації військовослужбовців, які брали участь у бойових діях у зоні АТО. Описано особливості змін життєвих перспектив особистості в кризових ситуаціях. Дослідження включало психологічний супровід сімейних пар (всього 38 осіб), які перебували в реабілітаційному центрі «Хирів-Рент-Інвест» м. Хирів (Львівська область, Самбірський район), що надає послуги 3 психологічної реабілітації постраждалим учасникам АТО. Емпіричне дослідження проводилось на основі напівструктурованого інтерв’ю та анкетування, проективних методик (малюнок «Острів моєї мрії», «Наш будинок»), порівняльного аналізу життєвих перспектив в кризових ситуаціях (І. Калінаускас). Виявлено розбіжності в змінах життєвих перспектив жінок і чоловіків в кризових ситуаціях. Встановлено, що у чоловіків проявляється змішаний тип стереотипів - небажання втручатись у вирішення проблеми, прояви знецінення свого життя, відсутність значущих цінностей і смислів. Було підібрано індивідуальні та групові методи психотерапевтичного впливу на процес гармонізації життєвих перспектив, планів, цінностей особистості. Показано вплив кризових ситуацій на побудову нових цілей та стратегій їх досягнення. Визначено та апробовано методики роботи 3 жінками і чоловіками на відновлення часово-просторових орієнтацій, минулого, сьогодення та майбутнього. Психологічна підтримка включала індивідуальні консультації, заняття в групах, арт-терапію, обговорення життєвих ситуацій. Показано важливість розвитку життєвих стратегій особистості, що активують побудову нових перспектив у процесі самодетермінації розвитку особистості.

Ключові слова: життєві перспективи, учасники АТО, психологічна реабілітація, кризові ситуації, зміни життєвих стратегій чоловіків та жінок. 